\title{
“Unsex me here" Lady Macbeth as a Disruptive Force in Macbeth
}

Saman Ali Mohammed/ University of Human Develpement /College of Languages/ English Department

\section{Introduction}

William Shakespeare's Macbeth was most likely written in 1606, three years into the reign of James I, James VI of Scotland since 1567 before he achieved the English throne in 1603. Macbeth is Shakespeare's shortest tragedy yet it is one of his most influential and emotionally intense plays. Macbeth portrays "the paralyzing, almost complete destruction of human spirit" (Shanley 307). Like most of Shakespeare's plays, Macbeth deals with the question of kingship and portrays the "problems of legitimacy and succession" surrounding serious political power that belonged to the monarch, the court and the royal councils (Hadfield 27). Numerous historical and literary studies have been conducted about various topics in Macbeth such as human desire, cruelty, and guilt. Gender role and its relation with power also have a great significance to the interpretation of the play.

Shakespeare substantially emphasizes the male-female relationship and gender dynamic and does not seem to treat gender simply as binary example of male/female. Shakespeare shows the relationship between gender and power which can be related to the patriarchal discourse of early modern England. He portrays women as major determinants in men's actions but "their function varies throughout the canon" and also in distinct categories of either "good or evil, victims or monsters" (Berggren 18, 11). Men are portrayed as strong willed and courageous, but female character like Lady Macbeth is also given a ruthless, power-hungry personality, which is typically, in the period, more associated with masculinity. Lady Macbeth, one of the main characters in Macbeth, is deeply ambitious and her role is essentially important to further understanding Shakespeare's presentation of female characters. In this paper, I will provide a brief context of Macbeth in terms of contemporary issues about sovereignty. I will closely examine the role of women in Macbeth, precisely Lady Macbeth, in Macbeth's downfall, particularly focusing on how and why Lady Macbeth is an unsettling and disruptive force to the order of the sovereignty. The paper will cover the contemporary issue of witchcraft, to suggest that Lady Macbeth's gender can be associated with supernatural subversion, as well as sexual temptation and the period's perspective about it. The paper discusses masculinity in relation to Lady Macbeth and the relationship between the plays actions and the natural order to suggest that natural order better reveals Lady Macbeth's disruption as well as the notion of monster in Macbeth. This essay will end by discussing the significance of the events that happen to both Macbeth and Lady Macbeth after the murder act and a conclusion.

Key Words: Witchcraft, Patriarchy, Maternity, Sovereignty, Order, Power, Ambition, Femininity 
After the accession of James 1, Shakespeare appears to have become more concerned with existence and form of political and legal institutions (Hadfield 150). James's accession gave England a monarch ruled again by a male who closed Elizabeth's ruling. Critics' discussions of Macbeth have often assumed a significant correspondence between James I's accession and Shakespeare's composition of Macbeth sometime soon after (Hadfield 2, Regan 19, Mangan 86, Nicholas 1). Shakespeare seems to examine the political succession of a male leader over a female one in the play; the arguable demonization of Lady Macbeth might be seen as a dramatization and unsettlement of maternity by patriarchal authority. The new masculine order seems to dramatize James's restriction over maternal extension emphasizing himself as a patriarchal icon in his Kingship. In a patriarchal society men had dominant roles and they had a male heir and women were not expected to go against patriarchal ruling; authority rested with the father, and the wife's authority was over children and the servants. (McDonald 256).

Furthermore, the dramatization of the supernatural in Macbeth reflects King James' passion in the study of witchcraft since in 1597 he wrote Daemonologie, an influential text in which he contended that witchcraft was a reality and that its practitioners must be punished (Joanna 38). For King James I, both the witch and the hysteria diagnosis were conceived of as "a proper expression of patriarchal governance ... as apt description of unruly femininity" (Munro 25). Such situation is shown when Lady Macbeth drives Macbeth to murder and she suffers from the consequences after that shows a link in both "the demonic and hysterical" (Joanna 25). For instance, the Doctor believes that the cure is "therein the patient/ must minister to himself" which can indicate her demonic crisis situation. Furthermore, looking at hysteria, the body of the sufferer is "inscribed with and ideological construction of femininity", but the female bodies "become docile bodies" that are "habituated to external regulation, subjection, transformation, improvement" which seems important to apply to Lady Macbeth's unbinding femininity (Bordo 166, 169). Her situation insightfully seems to show the reflection of political issues of gender and power of the time as Macbeth "becomes the offspring of a disorderly feminine imagination" (Joanna 42).

When Shakespeare wrote Macbeth, then, witchcraft was a topic of considerable interest. Shakespeare seems to expose the vicious influence of Lady Macbeth through a comparison with the witches. Witches were associated with "afflict[ing] all that is considered unholy, ungodly, and unnatural; they embody a specter of a world in which women rule over men" (McGuire 111). The witches in act I scene I confront Macbeth and tell him a prophesy to become King: "All hail, Macbeth, thou shalt be king hereafter!" (I.III.50). When Lady Macbeth reads Macbeth's letter about the witches prophesies, she immediately seems to echo their destructive evil spirits when in a soliloquy she says:

Glamis thou art, and Cawdor; and shalt be

What thou art promised: yet do I fear thy nature

It is too full o' the milk of human kindness ...

Than wishest should be undone.

That I may pour my spirits in thine ear ...

(I.V.14-25). 
In her embrace of spiritual power, Lady Macbeth exhibits a strange emasculating influence in her language over her husband that seems to parallel the witches. She tells the spirits, "unsex me" and "fill me from the crown to the toe, top full of direst cruelty" which shows her serious and potential threat to the natural order because she invites devil spirits and "offers her reproductive capabilities for demonic ends" (I.V.40, Joanna 41). Her representation as a destructive germ yet hidden in the essence of state order and her becoming a threat to the patriarchal order is exposed through her "sexual potency and fertility" she shares with the witches (Laoutaris 178). For instance, Macbeth's interaction with the witches confuses him "You should be women/ And yet your beards forbid me to interpret/ That you are so", and Lady Macbeth's attempt to unsex herself also provide a similar situation because she cannot escape from her biologically constructed body (I.III.45). Lady Macbeth's dominant power and sexual ambivalence seem to be connected to "the demonic and mirror the obscure gender identifications of the bearded witches" (Marcus 105). She unveils a desire to conclude her destiny through the control of bodily substances; "substances associated with the dangerously permeable female reproductive body" (Laoutaris 185). Lady Macbeth's evil force is better portrayed through her yearn for demonic powers to transform her into a witch that is associated with destruction.

Joanna Levin defines a witch as a woman who submits to Satanic forces and invokes evil spirits (22). As mentioned earlier, the crude appearances of the witches shocks and confuses Macbeth and he addresses them as "Speak if you can: what are you?" which can powerfully indicate their evil being and their border between female and object or non-human. 'What' and not 'who' that can pose whether they can be called human women (I.III.48). Comparably, when informed about the Duncan's visiting, Lady Macbeth says, "Come, you spirits/ That tend on mortal thoughts, unsex me here ..." (I.V.40-48). Such language portrays Lady Macbeth like the witches in a distinct sphere and defying patriarchal authority and becoming a threat to the gender system. Her attempt to unsex herself and her masculine indifference to death similarly "makes her a terrifying presence that is and is not a woman" (Munro 31). Like the witches, Lady Macbeth shows her nonconformity and general sense of empowerment and becomes "an instrument of fatality" (35). Lady Macbeth's portrayal in "an environment alive with evil spirit" shows her demonic purpose as a disruptive force in the body of monarch and stages the early modern fear that women might take power (Mary 152, Scot 144). Furthermore, there seem to be a similar mindset re-occurring with James's patriarchal iconography, setting itself against female rule of post-Elizabeth because Lady Macbeth reveals the idea of 'monstrous' rule of the powerful woman: "It is more than a monster in nature that a woman shall reign and have empire above man" (Knox NA). One possible reading of Lady Macbeth seems to suggest her "as a revivified scapegoat figure who gathers up yet once more the residual power of the image of Elizabeth" (Marcus 104). Such portrayal of Lady Macbeth seems to show Shakespeare's skepticism about the nature of women and undermines the notion of perceiving women as weak, but rather as forces that can be devastating if not bounded.

Lady Macbeth uses her sexuality as a weapon to tempt her husband and drives him to do what he dares not to execute. In her soliloquy, she says, "That I may pour my spirits in thine ear; And chastise with the valour of my tongue/ All that impedes thee from the golden round" (I.V.26-30). Her approach is "saturated with sexuality, and her weapon is a kind of sexual blackmail" that can 
confine Macbeth's thoughts and nurture his desire (Rauberr 61). Lady Macbeth seems to suppress her "feminine" instincts towards compassion and motherhood, instead uses them to seduce her husband into taking action. She is aware of his ambitious and believes that he's also too "kind" to do what it takes to murder Duncan thus she "chastise" him with the "valour of [her] tongue," to drive him into taking action and becoming "crown'd withal". Her language indicates that women's deep emotions and compassions as sources of warmth and commonality can also be misdirected towards brutality and distortion because her 'tongue' seems to portray her not as idle chatter but aggressive, military, or even phallic force. She has "a fierce, competitive, highly sexualized spirit bent upon particular ambition and sex against the general good" and such evil and sexual thoughts are promiscuously mixed in her mind (Holloway 138). She directs her desire away from him and towards "an image of future glory" that like a baby forces him to follow (Joanna 41). When she says, "I have given suck and know How tender 'tis to love the babe that milks me", this breastfeeding shows one of the biological traits of women and suggests a sexual discourse with her husband. (I.VII. 54-56). Targeting Macbeth's sexual desire is attacking a part that seems if unrestrained, would lead to major anarchy. Shakespeare portrays the inversion of typical seventeenth century gender and social roles because Lady Macbeth is established as the dominant partner in the relationship. Since husbands were supposed to rule their wives, Lady Macbeth's plan resembles treason of taking power that doesn't belong to her; she demonstrates patriarchal ideals of governance which endangers patriarchal belief and causes disturbance.

According to Berggren, early modern England seems to have profound fear of female sexuality and have attempted to control it (9). Lady Macbeth is the "undisciplined mad woman" or "a seductive unsatisfied wife" who to satisfy her unbounded desire, is ready to cause any disorder (27). As a deviant character under dark power, she departs her sexuality from a procreative potential to "breed[ing] villainy rather than children" and by fulfilling her sensual needs, the cycle of destruction completes (Berggren 24). Lady Macbeth renews the innate desire of her husband and leaves him with willingness to murder through her language "Come, we'll to sleep ... We are yet but young indeed". Her highly sexualized temptation and the unruliness of her sexuality seem to destroy every discipline and boundaries that Duncan ties the family together with (Holloway 138). She appears to some critics to be "the most commanding and perhaps the most awe-inspiring figure that Shakespeare drew" and her sexuality seems to work powerfully and influentially over Macbeth to "undo his decision not to kill Duncon" (McGuire 3). Her sexual seduction leaves a contaminated effect on Macbeth and threatens to turn the Kingdom upside down. Her sexual portrayal and seems to suggest that surrendering to female sexual desire and attraction altogether threatens to remove men from logical thought which brings no good consequences.

Shakespeare portrays women as a threat and disruptive forces to the established patriarchal order of the time. Lady Macbeth appears to manipulate her husband and "unsettle[s] conventional norms of gender" by attacking and questioning his masculinity. (Regan 99). Her view of what constitutes man and honor so "narrowly equated with valor" that it "could have disastrous consequences" (Hattaway 14). In contrary, Macbeth is portrayed to have moralistic perspective that does not allow him to commit such horrendous crime: "We will proceed no further in this business" (I.IIV.31). However, Lady Macbeth influentially attacks a concept that can threaten Macbeth's 
entire being. After Macbeth rejects to murder Duncan, she tells him "art thou afeard/ To be the same in thine own act and valor ... Wouldst thou have that which thou esteem'st the ornament of life/ And live a coward in thine own esteem" (I.VII.39-43). Her mockery of her husband's manhood leads her to proclaim her own unwomanly resolution because, in the period, the ideal Renaissance man was a man of "absolute honesty and integrity" and good names and reputation are close to their ethical values (Watson 28). She "arouses him with a taunt no man can be and least of all a solider" which is being "coward" which immensely influences her husband because of the highly valuation of masculinity by patriarchal society (Dusinberre 282). Lady Macbeth knows his weakness and confronts him with no doubt or conflict and seeks "to catch the nearest way" to the object he desires, because she seems to find "no separation between will and deed" (280). Manipulating her husband, Lady Macbeth stands against the patriarchy and the requirements of the wife to be submissive to men's orders because they are made to "serve and obey man, not to rule and command him" (Knox NA). Shakespeare offers Macbeth's behavior as profound proof to suggest that women can be as ambitious and cruel as men.

Lady Macbeth drives Macbeth to act based on her definition of manhood and masculinity, of taking action and murdering the king "possessed with devil passion" (Knight 150). She seems is aware of her control over him, undermines his manhood and brings out the evil within him through her power of manipulation: "when you durst do it, then you were a man/ And to be more than what you were, you would/ Be so much more the man" (I.VII. 49-51). Her strategy seems to be of providing an image of a secure world through his achieving superiority after he achieves the crown. Her insistence on the concept of manhood and murder violates values and norms that dictate appropriate actions for men. Providing an image of what she would execute with her own child further destabilizes and bewilders Macbeth's position and drives him to act, she tells him, "I have given suck, and know/ How tender tis to love the babe that milks me" but she will "plucked my nipple from his boneless gums/ And dashed the brains out" (I.VII.54-59). Furthermore, her influential approach provokes Macbeth to be devoted to murdering Duncan and leads him to lose himself which seems the most tragic of all because although he rejected the deed, Macbeth later asks: "Bring forth men-children only/ For thy undaunted mettle should compose/ nothing but males" (I.VII.74). What Shakespeare portrays seems to be a differentiation between "the physical courage of the hero with his imaginary apprehensions and moral scruples" (Watson 245). Lady Macbeth presents a threat to patriarchy because she associates masculinity with exposed aggression and violence and whenever she talk about manhood, violence follows causing further disruption. Macbeth later provokes the murderers he sends to kill Banquo by questioning their manhood; adopting Lady Macbeth's rhetoric.

Shakespeare's constant subversion of male and female role in the submission of men to dominant women seems to show his feelings of a flaw in the society's typical perceptions of natural order. Lady Macbeth breaks the constraints of her society through deception and manipulation because she is fearless and eager to achieve her ends. Her desire to "unsex me here" and her attempt to take part in Duncan's murder is "blocking all natural scruples, turning her life giving milk bitter" (Belsey 134). She plants plots and becomes a brain behind Macbeth's actions because her manipulative approach portrays Macbeth's execution of murdering Duncan as a "hired murder 
whose claim to be a man excites his scorn" (Dusinberre 285). Shakespeare suggests that women can be violent and caustic because Lady Macbeth is shown to "pervert the meaning of manhood as a way of taunting her husband with cowardice" (134). Her influence on her husband through the definition of manhood leads the political order portrayed in the beginning of the play into anarchy. Her behavior that contrasts the established belief and expectations about women leads Macbeth to be "too unmanned by his own excess of manly action to heed her jibes" causing destruction and anarchy (Dusinberre 285). Such portrayal of Lady Macbeth seems to indicate Shakespeare's support of patriarchy and fear of unbinding femininity.

Lady Macbeth "lapses from womanliness", yet she seems unable to separate herself form womankind (Klein 240). She is a threat once she attempts to be empowering the feminine and disempowering the masculine. Not only feminine trait like being soft, submissive and vulnerable, but also women's subordination to men is reversed in the figure of Lady Macbeth (Mcdonald 256). In order to function as Macbeth's partner in the deed, she has to "negate her own body and such stereotypical feminine virtues as pity, remorse and compunction" (Meron 124). Characteristically, she has deviated from her womanliness, but she is "a slave of her own body" and attempts to refit her body for masculine deeds and a masculine control over her memory that Macbeth has lost (Wilder 158). Macbeth clearly seems to have an incomplete masculine self-discipline to control himself against committing a murder which shows that "masculine mnemonic discipline in the play is modeled on Lady Macbeth's example rather than the reverse" (Wilder 158). With an embodiment of masculine power Shakespeare seems to suggest that "the unsettled gender dynamic between Lady Macbeth and Macbeth creates unnatural and physically invasive female memory pedagogy" (Wilder 158). Her femininity seems to suggest being the cause of disruption and associated with chaos and destruction. Her deviation is also against religious perspectives that women should "try lovingly bring[ing] errant husbands back into virtuous ways" and obey both God and their husband unless their husband acts in opposition to a divine law. (Klein 240). She is portrayed as a woman of "superior intelligence, eloquence, determination", yet she is dominated by desire and ambition that "like an evil genius goads her husband to his damnation" (Ziegler 124). Her digression from compassionate womankind causes an already degenerate Scotland desperately in need of civility because Scotland suffers under the barbaric rule of Macbeth. Lady Macbeth calls the spirits to "Come to my woman's breasts/ And take my milk for gall, you murd'ring ministers" which further indicates her anarchic femininity and her drift from womankind (I.V.48).

Lady Macbeth has already become unnatural and acts against and violates nature in multiple ways. Her urging Macbeth to murder is against the natural order of the universe both in terms of the nature of the crime and the relationship between Macbeth and Duncan as well as nature as order in the universe. Macbeth's crime is against natural loyalty and sovereignty of Duncan because his sin is a contradiction of truth and a substitute of reality. Having chosen evil, Lady Macbeth combats against good and drives her husband towards such end. For instance, Macbeth can realize that killing Duncon is evil: "if good, why do I yield to that suggestion whose horrid image doth unfix my hair and make my seated heart knock at my ribs against the use of nature?" (I.III.35-39). Her urging him to commit this crime is violating nature in the sense of ruining the tie of hospitality and blood relationship, "a perversion of the life forces of feasting, conviviality, social friendliness, and 
order; a destruction of nation-family" (Deen 61). Furthermore, Macbeth's great virtue and sound leadership is shown when he contemplates in a logical sense about why the murder is unnatural: "First, as I am his kinsman and his subject/ Strong both against the deed; then, as his host/ Who should against his murderer shut the door" (I.VII.13-15). These speeches seem to indicate the moralistic and rational thoughts of Macbeth about the unnaturalness of this deed and his awareness of it as contradiction of social propriety. However, Lady Macbeth constrains his thoughts and drives him to become unnatural to the good and moral of his conscience through bewildering speeches: "bear welcome in your eyes, your hand, your tongue- look like th'innocent flower, but be the serpent under't" (I.V.64). Her speech shows her with a hardened spirit and intention who forces Macbeth towards the fatal fulfillment of his desire through her "simple and smiling face" (Speaight 51). Her rhetoric reflects her own speech of being a flower outwards with Macbeth, but a serpent to seduce him to murder Duncon. Lady Macbeth's evil plots and speeches lead Macbeth towards "a vile transgression against friendship and kingship" because Duncon is a "paragon of kings-gentle, just, wise ... and also cousin to Macbeth" (Diamond 120). Shakespeare seems to examine the nature of evil and the corruption of the human soul through Lady Macbeth. Her evil influence is the opposite of humanity, the deviation from that which is natural for humankind because Lady Macbeth unties the blood-relationship desecration when destructively she is ready dashing out the brains of her son to lead Macbeth to act.

Macbeth's act is against the logical and natural order of his surrounding depicted through the unnatural and unwelcome phenomena that occur after. Macbeth has ambition and desire to have the thrown, but his powerful moral shield does not fully release him to kill Duncan and violate the natural state. Macbeth's monstrous murder act is accompanied by numerous unnatural occurrences in the natural realm because the nature of his deed is portrayed through his realization and understanding of his emotion through environmental changes and the stage direction of tempest and stride when he commits the murder. For instance, the pathetic fallacy of thunder and lightning that accompany the witches' appearance to the terrible storms that rage on the night of Duncan's murder reflects violations of the natural order and the corruption in the natural order and moral and political orders. Furthermore, when Macbeth finishes his deed of murder, he asks if Lady Macbeth has heard a noise and she informs her of "the owl scream, and the crickets cry" (II.I.4). Macbeth further witnessed two solider who one laughed in sleep and one "cried murder and that they awaked each other" (II.I.21). Such occurrences indicates that Macbeth's deed of revolt is a "defiance of the whole work of nature, and a conscious enlistment under the power of evil" and his becoming a great evil icon potentiality of life (Holloway 119). Furthermore, Macbeth himself wonders and his moral characteristic is shown through his situation after the murder act because he says "Methought I heard a voice cry 'sleep no more;" and he could not "pronounce Amen" after a prayer (II.II. 30,35). However Lady Macbeth thinks of these as "foolish thought" and asks Macbeth to not "consider it so deeply" (II. II, 21,29). Shakespeare seems to suggest that nature or natural order are echoing Lady Macbeth's deviation and destructive force since the usage of a tempest can suggest the moral confusion that Macbeth has lost along with an ethical perplexity.

Lady Macbeth eradicates the moralistic side of her husband, seems profoundly significant in the shaping of a noble man, and instead produces a beast or a tyrant. Shakespeare reveals Lady 
Macbeth's influence in creating a monster when she attempts to pour her spirits in to him because she tells Macbeth "you lack the reason of all natures sleep" (III.IV.141). Her act suggests "impregnation, witchcraft ... the transfer of animal spirits from one person's body to another's" (Wilder 158). Through powerful wordplay, she plants in Macbeth "mingled feelings of fear and material longing, making him vulnerable to her perverse nourishment" (Mary 154). Lady Macbeth embodies a strict physical and mental control from the murder preparation to practical steps of post murder hand washing and her attempts to help Macbeth overcome Banquo's ghost. Shakespeare represents her as "her husband's depraved nurturer" especially metaphorically exchanging "her milk of human kindness" for evil she possesses; fittingly "her words encourage him to imagine her breast-feeding" (Mary 152). Her strategy metaphorically resembles giving birth to a new Macbeth; a monstrous birth that she milks. Lady Macbeth's indifference to the blood of her victim and her "sneering jibes at her husband" presents her as a creature "set apart by a strain monstrosity" that is difficult "to comprehend" but better shows her nature (Boyd 177). Macbeth's murder act, thus, shows a morally wrong act due to lack of reason disrupted by powerful and influential representation of his wife's promise of future glories and her inversion of evil and disruptive power she claims to be her own, creating a monster out of him.

Furthermore, Macbeth is "Shakespeare's most profound and mature vision of evil" and if the ultimate power would be moral order, Lady Macbeth has disrupted such order around the country: "Bleed, bleed poor country", says Macduff (Knight 140, IV.III, 31). Lady Macbeth strikes the right point to make Macbeth a tyrant because she drives him "to contemplate murder with hope rather than horror" in committing regicide in order to gain power. (Shanley 308). She creates a monster that she is unable to control because Macbeth sends murderers to kill Malcolm's family and Banquo without letting her know. Lady Macbeth's control of her own milk giving, in the period, suggests her "control over matters of dearth and survival" which portrays women with power enabling them to "control over their own reproductively" (Paster 244, 252). Her plots and mapping "pokes holes in his consistency and complacency" and drives him to a state where "his ambition ultimately and paradoxically clashes with his loyalty and obedience" (Lowrance 843). Macbeth's destruction and bloodshed, thus, is an association with disease and destruction to the healthy state of political order and the victory that Duncon and his family celebrate. Lady Macbeth, thus, is the force behind making the empty fantasies to hard reality especially when Macbeth says, "I am settled, and bend up/ Each corporal agent to this terrible feat" and causes fear and disorder in the country through his tyrannical influences (I.VII.80).

After Macbeth's murder of Duncan, Shakespeare uses the consequences aftermath happen to Macbeth and Lady Macbeth to better portray Lady Macbeth's disruptive force to the order of the country. She becomes mad and suffers from "melancholia and guilt of conscience" that her rational soul seems to distinguish a sin that is "against the divinely imprinted law of nature" (Kocher 341). She has a disastrous time having nightmares, and sleepwalking, which indicates her guilt. In her sleepwalking scene the Doctor believes "this disease is beyond my practices" and his remedy is "More needs she the divine than the physician" (V.I.56, 73). Although Macbeth insists demanding a cure, the Doctor believes the cure is "there in the patient/ Must minister to himself" (V.III.45). This speech indicates that Lady Macbeth has not considered the ethical and religious aspects of murder 
because she "repudiated the dictates of reason and her own conscience" (Klein 242). She miscalculates the consequences of her plan which can be the result of her not being restricted or tied to certain principles. Her asking for hand washing that "All the perfume of Arabia will not sweeten this little hand" reinforces her crime (V.I.49). Her crisis situation better shows her bad influence and the danger of female unbinding that creates a tyrant that disrupts the whole nation and brings her own downfall. On the other hand, when Macbeth executes the murder, he hears a voice saying, "Sleep no more" which is a signal of "Macbeth's thematic logic, the parallel between disordered nature and the oral darkness within, into the experiential logic of the event" (II.II.35), (Worthen 23). Furthermore, Macbeth's realization of the destruction he has caused just before Lady Macbeth's death can support the fact about her evil unsettling influence.

\section{Conclusion}

Naturally, it seems apparent that the king must be loyal to Scotland above his own interests; however, Macbeth brings only chaos to his country. His anarchy is depicted in the bad weather and bizarre supernatural events and he offers no real justice, instead engages in murdering of those he is suspicious of and sees as a threat, for instance, Banquo and his son. Although he seems to lament over "honor, love, obedience, troops of friends he lost" and devastatingly concludes life as "a tale told by an idiot", it is too late for him (Shanley 306, V.V.26). Shakespeare seems to suggest that killing a rightful King is an offense to order and an embodiment of tyranny. With the death of Macbeth, the play suggests the restoration and reestablishment of a healthy and natural relationship between sovereign and subject and a true King once more. Shakespeare returns power and order to the legitimate hands of a male ruler by the end of the play which further reinforces Lady Macbeth disruption portrayed through both herself and her husband's destiny of downfall.

In Macbeth, then, Shakespeare studies the role of female characters through Lady Macbeth. The gender and power relationship is crucially portrayed through Lady Macbeth showing the link between Shakespeare's composition of Macbeth and King James I's accession. She can be said to represent the female dominance that haunts James throughout his early English reign in association with Queen Elizabeth. Lady Macbeth becomes a destructive force to an order that Duncan and his family has established. She is portrayed as a symbol of the danger of an unbound sexuality, especially when her destructive force is assimilated with the witches' evil power and supernatural subversion. Through a powerfully sexual language and temptation, she encourages, through seduction, him to murder, which suggests the danger of surrendering to undisciplined sexuality. Lady Macbeth not only deviates from conventions, but also by threatens patriarchal values of masculinity. She undermines Macbeth's manhood, equating it with cowardice and aggression. Lady Macbeth subverts her role to a masculine role to enable her husband to act and It is this deviation from perceived 'womanliness' that creates a danger to the order. Lady Macbeth has become unnatural and merciless. She is disruptive as she increases Macbeth's ambition and becomes a catalyst for the unleashing his dark side and convinces him to murder King Duncan and made arrangements to make it possible. She destabilizes her husband by challenging devil spirit in her body that desires a supernatural power and brings out a tyrant or a monster out of him. The 
terrifying alteration in the "natural order" of the universe and Lady Macbeth's devastating situation and suicide shows her disruptive to the disorder as well as her dominance masculine role unleashing a series of catastrophes that nearly destroys a kingdom.

\section{Works Cited}

1. Belsey Catherine. "Gender and Family" The Cambridge Companion to Shakespearean Tragedy Ed. Claire McEachern. Cambridge: Cambridge University Press, 2003. 123-141. Print

2. Berggren Paula S. "The Women's Part: Female Sexuality as Power in Shakespeare Plays" The Woman's Part: Feminist Criticism of Shakespeare Ed. Carolyn Ruth Swift Lenz, Gayle Greene, and Carol Thomas Neely. Urbana; Chicago: University of Illinois Press, 1980. Print

3. Bordo SusanUnbearable Weight: Feminism, Western Culture, and the Body. Berkeley, Calif.: University of California Press, 2003.

4. Boyd Catherine Bradshaw. "The Isolation of Antigone and Lady Macbeth" The Classical Journal 47.5 (1952) 174-177 Web. Jstor 10 April 2013

5. Deen Leonard F. "Macbeth and Modern Criticism" The English Journal 47. 2 (1958): 57-67 Web. Jstor 15 March 2013

6. Diamond Catherine. "Kingdom of Desire: The Three Faces of Macbeth" Asian Theatre Journal 11. 1 (1994) 114-133. Web. Jstor. 25 March 2013

7. Dusinberre, Juliet. Shakespeare and the Nature of Women. Basingstoke: Palgrave Macmillan, 2003. Print

8. Hadfield Andrew. Shakespeare and Renaissance Politics. London: Arden Shakespeare, 2004. Print

9. Holloway, John. The Story of the Night: Studies in Shakespeare's Major Tragedies. London: Routledge \& Kegan Paul, 1961. Print

10. Hattaway Michael. "Shakespeare History Plays" The Cambridge Companion to Shakespeare's History Plays. Ed. by Michael Hattaway. Cambridge: Cambridge University Press, 2002. 3-23. Print

11. Levin Joanna. "Lady MacBeth and the Daemonologie of Hysteria" ELH 69. 1 (2002): 21-55. Web. Project Muse 25 April 2013

12. Klein Joan Larsen. "Lady Macbeth 'Infirm of Purpose'”. The Woman's Part: Feminist Criticism of Shakespeare Ed. Carolyn Ruth Swift Lenz, Gayle Greene, and Carol Thomas Neely. Urbana; Chicago: University of Illinois Press, 1980. Print

13. Knight, G.Wilson. The Wheel of Fire: Interpretations of Shakespearean Tragedy, with Three New Essays. London: Methuen, 1977. Print

14. Kocher Paul H. "Lady Macbeth and the Doctor" Shakespeare Quarterly 5. 4 (1954):341-349 Web. Jstor 03 April 2013

15. Knox, John, ca.1513-1572. The First Blast of the Trumpet Against the Monstrous Regiment of Women, 1558. Birmingham: Arber, 1878.

16. Laoutaris, Chris. Shakespearean Maternities: Crises on Conception in Early Modern England. Edinburgh: Edinburgh University Press, 2008. Print

17. Lowrance Bryan. "Modern Ecstasy': Macbeth and the Meaning of the Political” American Literature 79.4, (2012): 823849 Web. Project Muse 01 April 2013

18. Mangan Michael. A preface to Shakespeare's Tragedies. London: Longman, 1991. Print

19. Mary Floyd-Wilson. "English Epicures and Scottish Witches" Shakespeare Quarterly 57. 2 (2006) 131-161. Web. Jstor 29 March 2013

20. Marcus, Leah S. Puzzling Shakespeare: Local Reading and its Discontents. Berkeley, Calif: University of California Press, 1988.

21. McGuire, Philip C. Shakespeare: the Jacobean plays. London: Macmillan, 1994. Print

22. McDonald, Russ. The Bedford Companion to Shakespeare: an Introduction with Documents. Boston: Bedford Books of St. Martin's Press; Basingstoke: Macmillan, 1996. Print

23. Munro Robert. "Lady Macbeth: A Psychological Sketch" The Journal of Speculative Philosophy 21. 1 (1887): $30-36$ Web. Jstor 20 April 2013

24. Regan Stephen. "Macbeth". Shakespeare: Texts and Contexts Ed. Kiernan Ryan. Basingstoke: Macmillan in association with the Open University, 2000. Print

25. Scot Reginald. "Debates on Witchcraft: The Discovery of Witchcraft" Church History 52. 4 (1983):131-138 Web. Jstor. 01 April 2013.

26. Shanley J. Lyndon. "Macbeth: The Tragedy of Evil" College English 22.5 (1961): 305-311 Web. Jstor 01 April 2013

27. Shakespeare William. The Tragedy of Macbeth Ed. by Nicholas Brooke. Oxford: Clarendon Press, 1990. Print 
28. Speaight, Robert. Nature in Shakespearian Tragedy. London: Hollis \& Carter, 1955. Print

29. Watson Robert N. "Tragedies of Revenge and Ambition" The Cambridge Companion to Shakespearean Tragedy Ed. Claire McEachern. Cambridge: Cambridge University Press, 2003. 160-181. Print

30. Wilder, Lina Perkins. Shakespeare's Memory Theatre: Recollection, Properties, and Character. Cambridge, UK; New York: Cambridge University Press, 2010. Print

31. Watson, Curtis Brown. Shakespeare and the Renaissance Concept of Honor. Princeton: Princeton U.P., 1960. Print 32. Worthen W. B. "The Written Troubles of the Brain": Sleep No More and the Space of Character Theatre Journal 64.1 (2012) 79-97 Web. Project Muse 27 March 2013

33. Ziegler Georgianna. “'Accommodating the Virago' $19^{\text {th }}$ Century Representation of Lady Macbeth" The Matter of Difference, Materialist Feminist Criticism of Shakespeare Ed. Valerie Wayne. Hemel Hempstead: Harvester Wheatsheaf, 1991. Print 